\title{
A GLOBAL AND LONG-RANGE PICTURE OF
}

ENERGY DEVELOPMENTS

Wolf Häfele

International Institute for Applied Systems Analysis, Austria

RP $81-8$

May 1981

Reprinted from Science, volume 209, 4 July (1980)

INTERNATIONAL INSTITUTE FOR APPLIED SYSTEMS ANALYSIS

Laxenburg, Austria 
Research Reports, which record research conducted at IIASA, are independently reviewed before publication. However. the views and opinions they express are not necessarily those of the Institute or the National Member Organizations that support it.

Reprinted with permission from Philip H. Abelson and Ruth Kulstad, editors. The Science Centennial Review, American Association for the Advancement of Science, Washington, DC, 1980, pp. 156164. The article was originally published in this form in the Centennial Issue of Science 209(4 July):174-182, 1980.

Copyright $\odot 1980$ American Association for the Advancement of Science.

All rights reserved. No part of this publication may be reproduced or transmitted in any form or by any means, electronic or mechanical, including photocopy, recording, or any information storage or retrieval system, without permission in writing from the copyright holder. 


\section{FOREWORD}

During the period 1973-1979 the Energy Systems Program Group at the International Institute for Applied Systems Analysis had as its central aim to conceive and construct a long-range picture of global energy developments. The article reprinted here sums up, for two benchmark scenarios, the balance of supply and demand through 2030 .

The article appeared originally in the Centennial Issue of Science, volume 209, 4 July (1980).

For a detailed account of the work on which the results described in this article are based, as well as full treatment of the results of IIASA's energy analyses, see Energy Systems Program Group of the International Institute for Applied Systems Analysis, Wolf Häfele, Program Leader, Energy in a Finite World: A Global Systems Analysis, Ballinger, Cambridge, Massachusetts, 1981. A briefer account for the general reader prepared by the same group appears in Energy in a Finite World: Paths to a Sustainable Future, Ballinger, Cambridge, Massachusetts, 1981. An appendix to this reprint gives a list of other publications of the Energy Systems Program Group.

ROGER LEVIEN

Director 



\title{
A Global and Long-Range Picture of Energy Developments
}

\author{
Wolf Häfele
}

\section{A Time Frame for Global and \\ Long-Range Energy Developments}

In the middle of the last century wood was the predominant source of energy, meeting roughly 70 to 80 percent of the demand. This meant large-scale gathering and led to a first energy crisis, which was that were essential for the first industrial revolution. Figure 1 shows the decline and rise of market shares of various types of primary energy in the United States. The data are plotted in such a way that a logistic curve becomes a straight line. It should be noted that there are remarkable regularities in the

Summary. Most studies of energy supply and demand ignore either global interdependence or the long time spans necessary to adjust to new energy sources. The International Institute for Applied Systems Analysis has therefore studied on a global scale, for seven major world regions, the balance between energy supply and demand for the next 50 years. Reported here are the results for two benchmark scenarios. In the "low" scenario world energy consumption increases from today's 8.2 terawatt-year per year to 22 terawatt-year per year in 2030; in the "high" scenario, consumption increases to 35 terawatt-year per year. The study showed that time will be the limiting constraint in adapting the energy supply infrastructure to changing resource availability; resources will be available until the second half of the next century, but a strong shift will be required to low-grade fossil fuels such as shale oil and tar sands. Each scenario studied indicated increased environmental problems associated with increased use of fossil fuels, and potential geopolitical problems associated with the world distribution of resources.

overcome by a fundamental change in technology: Coal was used as a substitute for wood. The higher density of coal meant not only more energy but also easier storability and transportability, features

The author is deputy director of the International Institute for Applied Systems Analysis, Laxenburg. Austria. and leader of the Energy Systems Program at IIASA. data over extended time periods. One such regularity is the slope of these curves. Its constancy means continued logistic substitution of one source by another over decades. For the United States it has always taken roughly six decades for a new energy source to conquer 50 percent of the market. For the world as a whole the figure is ten dec- ades. The regularities of such market penetrations have been studied in great depth $(l)$. What is concluded here is that it is appropriate to consider the time frame 1980 to 2030 when developments of energy demand and supply and their underlying infrastructure are to be discussed.

It also seems appropriate to consider the world as a whole. Indeed, today roughly 25 percent of the world's energy supplies come from one place on the globe, the Middle East, and this creates a strong technical and political linkage for almost all parts of the world. On the demand side the situation is similar. For instance, a political debate continues to focus on the notion of a "new economic order" viewing the world as a whole and addressing the problem of developing the so-called "South" of the world. Although political in nature, this debate nevertheless makes it plain that the demand for energy must also be seen in such a perspective. By contrast, most of the major studies of energy approach the problem on a national scale and use a short- to medium-range planning horizon, say 10 to 15 years. While this is clearly necessary, it is not sufficient. Often the result of such studies is the identification of required imports; the feasibility of such imports is left open. Indeed, others may have planned to import the same barrel of oil. It is thus global comprehensiveness and consistency that must come into focus, particularly when the time frame reaches out to the year 2030 .

\section{The IIASA Energy Systems Program}

Such a global and long-range view characterizes the approach of the Energy Systems Program of the International Institute for Applied Systems Analysis at Laxenburg, near Vienna, Austria. IIASA was conceived in the late $1960^{\circ} \mathrm{s}$ 
with the idea of studying problems of civilization identified as likely to become overwhelming in industrialized nations in the 1970's and 1980's. The United States and the Soviet Union are the lead nations, but there were ten more nations to found the Institute in 1972 and five more nations have joined in the meantime, bringing the total to 17 member nations (2). The institute is nongovernmental, the member countries being represented by their academies of sciences or similar bodies. Topics of research include, among others, food, urbanization, environment, water, industrial management, energy, and the related mathematical methods. The Energy Systems Program started with the beginning of IIASA in 1973 and has now concluded a major study, Energy in a Finite World (3). Over the years more than 140 scientists from more than 20 nations, East, West, and South alike, have for longer or briefer periods joined the program. From the United States, for example, Alan Manne, Bernard Spinrad, Amory Lovins, Paul Basile, and others have participated in the study. An explicit attempt was made to incorporate as many views and to be as objective as possible. The idea was to understand the factual basis of the energy problem, that is, to identify the facts and conditions for any energy policy. Given the worldwide nature of the institute it was not the intent to go into the politics or societal aspects of the energy problem as seen from particular nations. In this article I report some major results of IIASA's Energy Systems Program.

\section{The Approach Taken and Its}

\section{Methodological Problems}

In choosing our approach to this global and long-range study our guiding idea was to understand the transitions that will be necessary when the fossil fuels now in use begin to run out. An attempt was made to determine the supply limits for energy from coal, nuclear, and solar sources, with special emphasis being given to the problem of local, renewable energy sources. We also studied the conceivable constraints on energy strategies, such as those imposed by the production of waste heat, the release of carbon dioxide, and the relative risks of each strategy. We found consistently that time is the most precious resource; and time therefore imposes the most severe constraint on possible actions. We then used our results to identify strategies appropriate for the transition from the present infrastructure of energy sup- ply and demand to a futuristic one with explicit emphasis on the evolving energy demand. Since it is not possible to make predictions 50 years into the future, and since such predictions require political and societal considerations that we did not include, we chose the method of scenario writing. We wished to stress internal consistency and global comprehensiveness. This required the development and application of a set of appropriate mathematical models (4), because only through quantification can one reach the degree of consistency required to prevent, for example, the same barrel of oil being assigned to two different countries or for two different purposes. However, one must be prudent in interpreting the numerical results thus obtained; they must not be take too literally. In fact, they must be seen as quantitative expressions of the more qualitative situations that underlie the scenarios. The goal is to understand and conceptualize the worldwide situation for the next fiv decades.

Since it is neither possible nor desirable to write scenarios for 150 nations, we chose instead to study seven world regions (see Fig. 2) selected mostly on the basis of economical status rather than geographical proximity. Region I, North America, has a developed market economy and is rich in resources. Region II, the Soviet Union and Eastern Europe, is characterized by its developed, planned economies and rich resources. Region III includes member countries of the OECD (Organization for Economic Cooperation and Development) (except North America) and is characterized by poor energy resources. Region IV is Latin America. Region V, Southeast Asia and Africa, is a developing region with a high population and only a few resources. Region VI includes the oil-rich Arab countries. Region VII includes the centrally planned Asian economies.
Fig. 1. Primary energy substitution, United States.
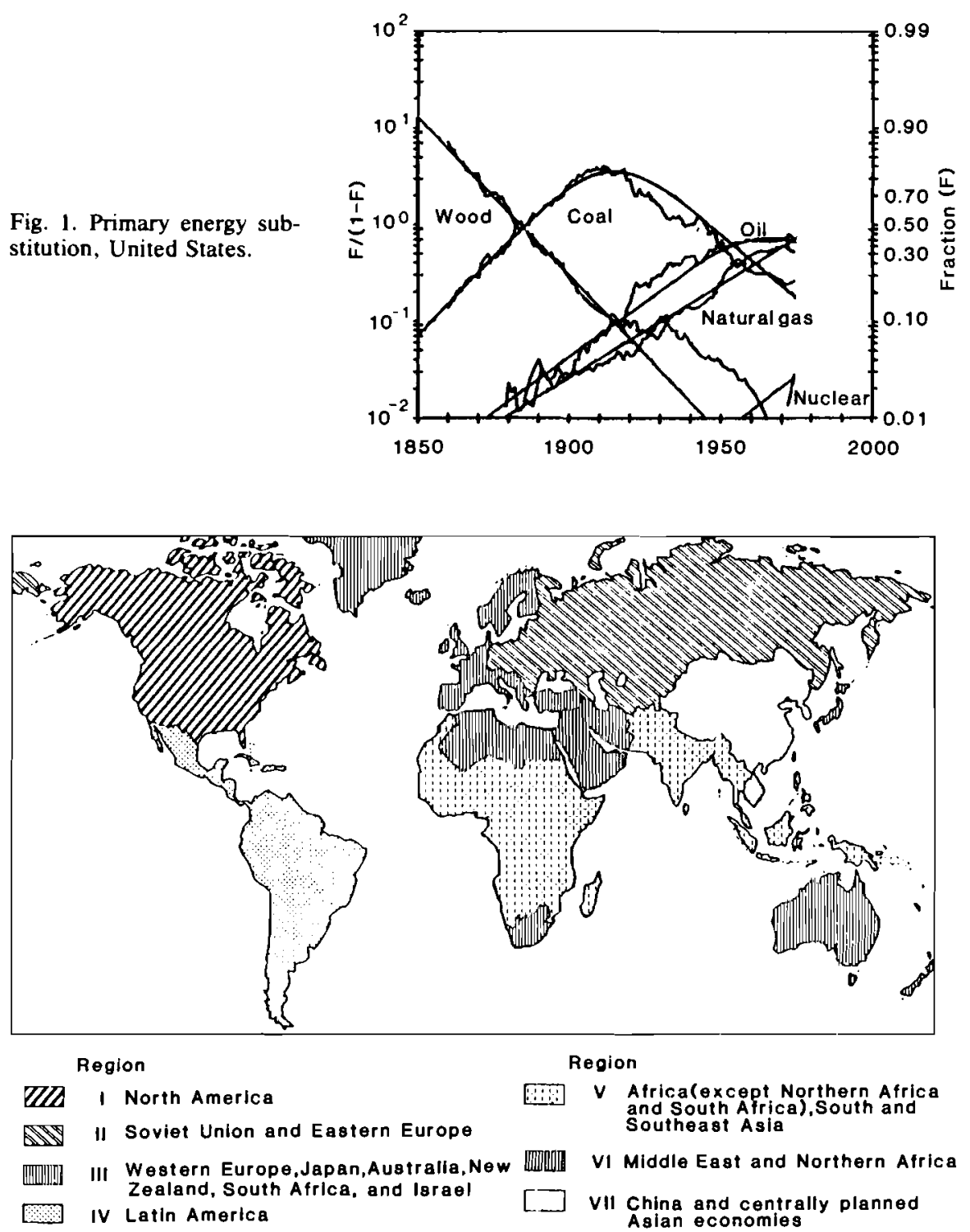

Fig. 2. The seven world regions. 
These regions were used to construct the two benchmark scenarios described below that provide an overall picture of the global energy situation. However, each individual nation or group of nations also requires a more specific analysis that is consistent with the overal global picture. Such work is now in progress. For example, the IIASA Energy Systems Program is engaged in an active dialogue with the European Communities in Brussels. The Communities, using a bottom-up approach, are planning specific energy strategies by adding up the expectations of the member countries, while IIASA, with a top-down approach, is providing the global picture of energy availability. The results have been both unexpected and helpful (5). A similar dialogue is going on between IIASA and Bulgaria, the Federal Republic of Germany, the Soviet Union and, to some extent, OPEC (Organization of Petroleum Exporting Countries) members and other nations and groups.

\section{Two Benchmark Scenarios}

Two benchmark scenarios have been elaborated in great detail. These are labeled "high" and "low," the former referring to a situation in which the demand for energy is relatively high, the latter to a situation in which the demand is relatively low. These scenarios allow for a certain inter- and extrapolation and thus leave the reader with a choice; both

Table 1. Historical and projected growth rates of gross domestic product (GDP), by region, for the high and low scenarios (percentage per year).

\begin{tabular}{|c|c|c|c|c|c|c|}
\hline \multirow[b]{2}{*}{ Region } & \multicolumn{2}{|c|}{ Historical } & \multicolumn{4}{|c|}{ Scenario projection } \\
\hline & $\begin{array}{l}1950 \\
\text { to } \\
1960\end{array}$ & $\begin{array}{l}1960 \\
\text { to } \\
1975\end{array}$ & $\begin{array}{l}1975 \\
\text { to } \\
1985\end{array}$ & $\begin{array}{c}1985 \\
\text { to } \\
2000\end{array}$ & $\begin{array}{l}2000 \\
\text { to } \\
2015\end{array}$ & $\begin{array}{c}2015 \\
\text { to } \\
2030\end{array}$ \\
\hline \multicolumn{7}{|c|}{ High scenario } \\
\hline I & 3.3 & 3.4 & 4.3 & 3.3 & 2.4 & 2.0 \\
\hline II & 10.4 & 6.5 & 5.0 & 4.0 & 3.5 & 3.5 \\
\hline III & 5.0 & 5.2 & 4.3 & 3.4 & 2.5 & 2.0 \\
\hline IV & 5.0 & 6.1 & 6.2 & 4.9 & 3.7 & 3.3 \\
\hline V & 3.9 & 5.5 & 5.8 & 4.8 & 3.8 & 3.4 \\
\hline VI & 7.0 & 9.8 & 7.2 & 5.9 & 4.2 & 3.8 \\
\hline VII & 8.0 & 6.1 & 5.0 & 4.0 & 3.5 & 3.0 \\
\hline World & 5.0 & 5.0 & 4.7 & 3.8 & 3.0 & 2.7 \\
\hline I + III* & 4.2 & 4.4 & 4.3 & 3.4 & 2.5 & 2.0 \\
\hline $\mathbf{I V}+\mathrm{V}+\mathrm{VI}^{*}$ & 4.7 & 6.5 & 6.3 & 5.1 & 3.9 & 3.5 \\
\hline \multicolumn{7}{|c|}{ Low scenario } \\
\hline I & 3.3 & 3.4 & 3.1 & 2.0 & 1.1 & 1.0 \\
\hline II & 10.4 & 6.5 & 4.5 & 3.5 & 2.5 & 2.0 \\
\hline III & 5.0 & 5.2 & 3.2 & 2.1 & 1.5 & 1.2 \\
\hline IV & 5.0 & 6.1 & 4.7 & 3.6 & 3.0 & 3.0 \\
\hline V & 3.9 & 5.5 & 4.8 & 3.6 & 2.8 & 2.4 \\
\hline VI & 7.0 & 9.8 & 5.6 & 4.6 & 2.7 & 2.1 \\
\hline VII & 8.0 & 6.1 & 3.3 & 3.0 & 2.5 & 2.0 \\
\hline World & 5.0 & 5.0 & 3.6 & 2.7 & 1.9 & 1.7 \\
\hline$I+I^{*}$ & 4.2 & 4.4 & 3.1 & 2.1 & 1.3 & 1.1 \\
\hline$I V+V+V I^{*}$ & 4.7 & 6.5 & 5.0 & 3.8 & 2.9 & 2.6 \\
\hline
\end{tabular}

*Presented for purposes of comparison with data in $(18)$ and other global studies which exclude centrally planned economies. Note: Historical and projected values of GDP in constant (1975) U.S. dollars are given in Chant (19).

Table 2. Final energy (in the year 2030) in the two scenarios compared to final energy calculated with historical elasticities.

\begin{tabular}{|c|c|c|c|c|c|c|}
\hline Region & $\begin{array}{c}\text { High } \\
\text { scenario } \\
\text { (GW-year/ } \\
\text { year) }\end{array}$ & $\begin{array}{l}\text { With his- } \\
\text { torical } \epsilon_{\mathrm{f}}^{*} \\
\text { (GW-year/ } \\
\text { year) }\end{array}$ & $\begin{array}{c}\text { Differ- } \\
\text { ence }{ }^{\dagger} \\
(\%)\end{array}$ & $\begin{array}{c}\text { Low } \\
\text { scenario } \\
\text { (GW-year' } \\
\text { year) }\end{array}$ & $\begin{array}{c}\text { With his- } \\
\text { torical } \epsilon_{\mathrm{f}}{ }^{*} \\
\text { (GW-year/ } \\
\text { year) }\end{array}$ & $\begin{array}{l}\text { Differ- } \\
\text { ence }{ }^{\dagger} \\
(\%)\end{array}$ \\
\hline I & 3,665 & 6,921 & 47 & 2,636 & 4,036 & 35 \\
\hline II & 4,114 & 5,355 & 23 & 2,952 & 3,850 & 23 \\
\hline III & 4,375 & 6,037 & 28 & 2,987 & 3,761 & 21 \\
\hline IV & 2,641 & 4,385 & 40 & 1,656 & 2,481 & 33 \\
\hline $\mathrm{V}$ & 3,175 & 6,900 & 54 & 1,876 & 3,121 & 40 \\
\hline VI & 1,620 & 2,590 & 37 & 850 & 1,015 & 16 \\
\hline VII & 3,196 & 8,849 & 64 & 1,589 & 3,536 & 55 \\
\hline World & 22,786 & 41,037 & 44 & 14,546 & 21,800 & 33 \\
\hline
\end{tabular}

* Calculated by using historical (1950 to 1975) final energy-to-GDP elasticity ( $\left.\epsilon_{t}\right)$ for each region. †Calculated as final energy using historical $\epsilon_{q}$ minus IIASA scenario projection divided by final energy using historical $\epsilon_{\text {r. }}$ scenarios result in a mix of energy sources. Three alternative scenarios were also investigated: one in which there is a worldwide nuclear moratorium, one in which there is an all-out effort to develop nuclear energy, and one incorporating very strong energy conservation measures. Here attention will be given to the high and the low scenarios.

\section{Energy Demand}

Population growth, economic growth, technological progress, and structural evolution are the four principal determinants of energy demand. According to Keyfitz (6), an overall population growth from 4 billion today to 8 billion by the year 2030 has been considered, and the disaggregated numbers for the seven world regions were used in the analysis described here. Eight billion is a conservative estimate, since it implies that by the year 2015 the average family will have only two children, the age structure then prevailing being the cause of world population growth even after 2015. Although one can make estimates of population growth, it is impossible to predict economic growth rates, because these are strongly influenced by innovations, know-how, and skills of all kinds. Instead, one has to make assumptions. We intended to be conservative and therefore assumed declining economic growth rates throughout. Further, we recognized that developing countries would be limited in their growth potential to one or two percentage points above the growth rates of the developed countries (7). This implies that for the next few decades the developing countries will still be tied to the rest of the world economy through trade and other relations. It is unrealistic to assume a high growth rate in the developing part of the world while the OECD countries have a low or zero growth rate. When constructing the scenarios we found that growth rates are generally restricted by the conditions required for interregional consistency and the balance of energy demand and supply. Thus, if one connects the 1975 and 2030 points by an exponential curve (the decline of growth rates therefore not being expressed) one obtains a 3.4 percent rate of economic growth for the high scenario and 2.4 percent rate of growth for the low scenario. Disaggregated in time and space the picture is as explained in Table 1.

On the basis of these assumptions we estimated the related energy demands. It is particularly important to distinguish between primary and final energy, the 
former being crude oil or coal, for example, the latter gasoline or electricity. For the long-range and globally comprehensive scenarios it is not feasible to base an evaluation on prices and elasticities. It is more appropriate to consider, and account for, the physical end uses of energy. Such accounting has been formalized in the MEDEE model ( 8$)$ and pioneered by the Grenoble group (9), among others. It calls for the identification of life-style, as well as economic and technical parameters related to energy end uses. A problem associated with the MEDEE model is internal consistency. Usually one can force such consistency by relying on an input-output approach, for example. But when we consider the evolution of energy infrastructures we ask for the evolution of input-output coefficients and therefore only shift the problem somewhere else. Thus the results obtained are subject to debate, but so is the future of the economies in question. Generally it was assumed that a significant degree of energy conservation would take place.

Table 2 shows the aggregate results for the seven world regions and their differences with respect to historical trends. The high scenario provides for a higher degree of conservation because higher economic growth rates usually allow for more innovation and structural change. Physically, even higher degrees of energy conservation are possible. Energy consumption can be restrained either by not meeting needs or by substituting many of the services that come from energy with services that come from capital or labor. However, related to this are problems of the structure of the economies in question. For example, it may not be possible to maintain high levels of productivity if there is a substantial increase in the number of people seeking employment in the service sector. Such an increase could also have geopolitical implications, particularly in the case of larger nations. In fact, these problems reach far beyond the domain of energy. Here we chose not to make extreme assumptions. It was then legitimate to look for an overall indication of the nature of the two demand scenarios. Figure 3 shows the ratio of energy to gross domestic product, or, in other words, the overall energy intensiveness in the past and in the two scenarios. A certain regularity is evident, pointing to a decreasing energy intensiveness in general. It is felt that such regularity is one of the characteristics of the demand scenarios.

There is a major observation in connection with analyzing energy demand that is quite robust against parameter variations. In view of the balance between energy demand and supply, we found it necessary in our scenario writings to restrict the uses of hydrocarbons to those where substitution is difficult, for example, as chemical feedstocks. The transportation sector was also assumed to need hydrocarbons, because other end-use technologies (which could, for example, use hydrogen instead) will penetrate too slowly to make a worldwide difference before 2030 . It was then not surprising to find that in region II, long-range planning indeed requires the use of liquid hydrocarbons exclusively for chemical and transportation purposes. But this approach is not imperative. Chemical feedstock could also come from synthesis gas and more electricity might be used in the transportation sector. But scenario writing requires that we make such considerations explicit.

A demand for final energy leads to a demand for primary energy and therefore implies a combination of energy conversion processes. Such combinations result from the availability of fossil and nuclear fuels, from build-up rates of new conversion technologies, such as

Table 3. Two supply scenarios, primary energy by region, 1975 to 2030 (terawatt-year per year).

\begin{tabular}{|c|c|c|c|c|c|}
\hline \multirow{2}{*}{ Region } & \multirow{2}{*}{1975} & \multicolumn{2}{|c|}{ High scenario } & \multicolumn{2}{|c|}{ Low scenario } \\
\hline & & 2000 & 2030 & 2000 & 2030 \\
\hline I & 2.65 & 3.89 & 6.02 & 3.31 & 4.37 \\
\hline II & 1.84 & 3.69 & 7.33 & 3.31 & 5.00 \\
\hline III & 2.26 & 4.29 & 7.14 & 3.39 & 4.54 \\
\hline IV & 0.34 & I. .34 & 3.68 & 0.97 & 2.31 \\
\hline V & 0.33 & 1.43 & 4.65 & 1.07 & 2.66 \\
\hline VI & 0.13 & 0.77 & 2.38 & 0.56 & 1.23 \\
\hline VII & 0.46 & 1.44 & 4.45 & 0.98 & 2.29 \\
\hline Total ${ }^{*}$ & $8.21 \dagger$ & 16.84 & 35.65 & 13.59 & 22.39 \\
\hline
\end{tabular}

*Columns may not sum to totals because of rounding. Includes $0.21 \mathrm{TW}$-year per year of bunker fuel oil.

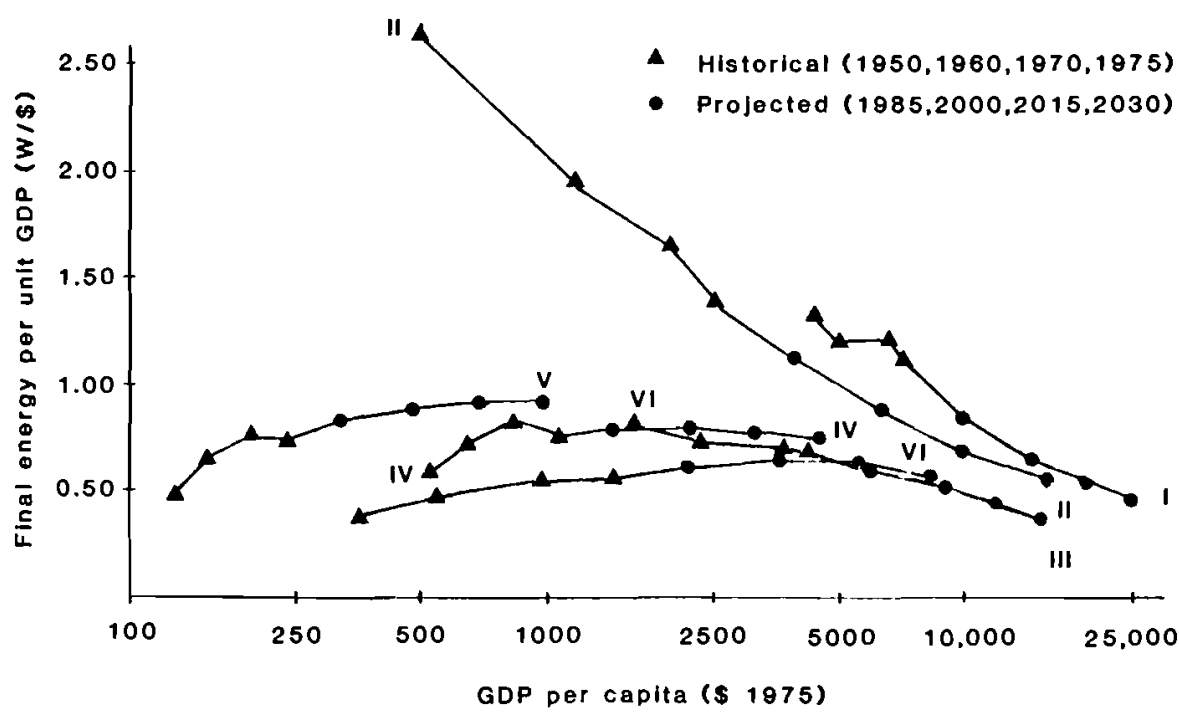

Fig. 3. Energy intensiveness in different world regions. coal liquefaction, and from cost optimization. A linear programming model, MESSAGE, was used to identify optimal combinations (10). Actually, discounted costs were optimized and this led to the usual question about the appropriateness of such optimization. However, the results obtained were characterized more by the constraints than by the type of the objective function. Indeed, a linear programming procedure accomplishes two things: it optimizes and it handles the many constraints that must necessarily be considered in an orderly fashion. In our scenarios the window of feasibility turned out to be small, that is, the problem was feasibility, not optimality.

Thus the required primary energy supplies are given in Table 3 disaggregated by regions. By the year 2030 the total global demand for primary energy is roughly 36 terawatt-year per year for the high scenario, and $22 \mathrm{TW}$-year per year for the low scenario (//). This compares with $8.2 \mathrm{TW}$-year per year today. Thus, between 1975 and 2030, the demand for primary energy increases by a factor of 4.4 and 2.7 , respectively, for the high and low scenarios; on a per capita basis there is a 2.2- and 1.35-fold increase, respectively, in primary energy demand. It 
should be noted that the supply of energy continues to be very uneven. The ratio of energy supply in regions IV $+\mathrm{V}+$ VI + VII (the South) compared with regions I + II + III (the North) shows only a slight improvement. The ratio improves by a factor of 3 from 0.23 to 0.75 in the high scenario, and by a factor of 2.6 from 0.23 to 0.6 in the low scenario. Realistically, one must expect the growth of energy demand, at least in regions IV, V, VI, and VII, to continue increasing beyond the year 2030 , for reasons of population growth as well as reasons of economic growth. Thus, supply options must be evaluated against a yardstick of 2 to $3 \mathrm{TW}$-year per year if a contribution of about 10 percent of the 20 to $30 \mathrm{TW}$-year per year of the total global demand is to be envisaged.

Table 4. Two supply scenarios, global primary energy by source, 1975 to 2030 (terawatt-year per year).

\begin{tabular}{|c|c|c|c|c|c|}
\hline \multirow{2}{*}{ Primary source* } & \multirow{2}{*}{$\begin{array}{l}\text { Base } \\
\text { year } \\
1975\end{array}$} & \multicolumn{2}{|c|}{ High scenario } & \multicolumn{2}{|c|}{ Low scenario } \\
\hline & & 2000 & 2030 & 2000 & 2030 \\
\hline Oil & 3.62 & 5.89 & 6.83 & 4.75 & 5.02 \\
\hline Gas & 1.51 & 3.11 & 5.97 & 2.53 & 3.47 \\
\hline Coal & 2.26 & 4.94 & 11.98 & 3.92 & 6.45 \\
\hline Light-water reactor & 0.12 & 1.70 & 3.21 & 1.27 & 1.89 \\
\hline Fast breeder reactor & 0 & 0.04 & 4.88 & 0.02 & 3.28 \\
\hline Hydroelectricity & 0.50 & 0.83 & 1.46 & 0.83 & 1.46 \\
\hline Solart & 0 & 0.10 & 0.49 & 0.09 & 0.30 \\
\hline Other $\neq$ & $0.2 \mathrm{I}$ & 0.22 & 0.81 & 0.17 & 0.52 \\
\hline Total§ & 8.21 & 16.84 & 35.65 & 13.59 & 22.39 \\
\hline
\end{tabular}

* Primary fuels production or primary fuels as inputs to conversion or refining processes: for example, coal used to make synthetic liquid fuel is counted in coal figures. IIncludes mostly "soft" solar, that is, individual rooftop collectors; also small amounts of centralized solar electricity. " "'Other" includes biogas, geothermal energy, commercial wood use, as well as bunker fuel oil; for 2000 and 2030 , bunker fuel is not

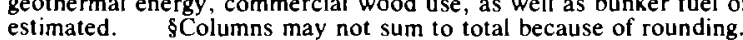

Table 5. Region VI (Middle East and Northern Africa) oil production rates and capacity and assumed production ceiling (million barrels of oil per day). Non-region VI OPEC countries are Venezuela, Ecuador, Nigeria. Gabon, and Indonesia. Eight OPEC member countries are in region VI; six in the Middle East (Saudi Arabia, Kuwait, United Arab Emirates, Iran, Iraq, and Qatar) and two in Northern Africa (Algeria and Libya).

\begin{tabular}{|c|c|c|}
\hline Region or country & 1975 & 1977 \\
\hline \multicolumn{3}{|c|}{ Production rates } \\
\hline OPEC member countries & 27.19 & 31.53 \\
\hline Minus non-region VI OPEC member countries & $-\quad 5.82$ & -6.52 \\
\hline OPEC and region VI countries & 21.37 & 25.01 \\
\hline Plus non-OPEC region VI countries* & +1.05 & +0.99 \\
\hline Region Vl & 22.42 & 26.00 \\
\hline Of which exported & 21.23 & 24.64 \\
\hline \multicolumn{3}{|c|}{ Production capacities $\dagger$} \\
\hline Saudi Arabia & 10.7 & 10.8 \\
\hline Iran & 6.5 & 6.8 \\
\hline Iraq & 3.0 & 2.6 \\
\hline Kuwait & 2.9 & 3.0 \\
\hline Libya & 2.3 & 2.5 \\
\hline United Arab Emirates & 2.3 & 2.3 \\
\hline Algeria & 1.3 & 1.0 \\
\hline Qatar & 0.6 & 0.7 \\
\hline Estimate of other region VI countriesł & 1.4 & 1.4 \\
\hline Region VI & 31.0 & 31.8 \\
\hline Estimated long-term region VI "ceiling": 33.6 & & \\
\hline
\end{tabular}

*Seven countries in the Middle East: Bahrain. Jordan, Lebanon, Oman, Syria, North Yemen, and South Yemen, and one in Northern Africa (Egypt). †Production capacities are estimates from the Department of Energy (20) for 1975 and from Petroleum Intelligence Weekly (2I) for 1977 . \$IIASA estimate. the other renewables have a rather low share. This is more an outcome of the cost optimization routine than a statement of the potential or desirability of such renewable resources. More will be said about this below. What must be emphasized here is the advent of two major technologies in the year 2000: synliquids and the fast breeder reactor. Synliquids should be interpreted as synthetic hydrocarbons of any kind, for example, methanol, gasoline, or even methane. But in the scenarios the demand for energy in liquid form was particularly pressing, and thus it was labeled as synliquid. It was assumed that the processes in question would be autothermal. (In autothermal gasification and liquefaction schemes both the process heat and the required hydrogen come from the coal itself, in addition to what is needed for the chemical coal content of the synfuels. This means a difference of a factor of 3 to 4 between autothermal and allothermal processes. In an allothermal process, the process heat and the required hydrogen are supplied exogenously, preferably by means of either nuclear or solar power.) To have synliquids and the fast breeder reactor in use by the year 2000 would mean an installed capacity of dozens of gigawatt-thermal or, what is equivalent, dozens of million tons of coal (tce). It would not be sufficient to have one or two demonstration plants by this time. Although there are regional differences in these requirements, this means that aggressive action in an overall context is required now.

of particular interest is the disaggregation by source in absolute terms as given in Table 4 . What is striking is the increase in oil use. This means a transition to ever higher production costs and, consequently, a transition to oil shale and tar sands. Also the production of gas increases. Perhaps most indicative is the case of coal. Many may argue that an increase of up to $12 \mathrm{TW}$-year per year (high scenario) is impossible. This may indeed be the case. But if we are to be globally comprehensive we must then ask: What will we have instead? The low scenario? More solar? Indeed, it was our intent in this scenario analysis to seek answers to such questions. Nuclear power takes on a medium-size share. It should be noted that all the numbers refer to thermal energy production per year; for example, the figure for light-water reactor plus fast breeder reactor in the low scenario is $5.17 \mathrm{TW}$-per year. This relates roughly to an installed capacity of 3000 gigawatt-electric by the year 2030 , which is quite close to the results obtained in a recent study on the future of nu- 
clear power on a worldwide basis (I2). Solar power here refers to local, or "soft," uses of solar power.

\section{More Oil}

The most important aspect of Table 4 is the increase of what is labeled as oil. How could this be achieved? Both production and resource constraints must be considered. Figure 5 shows production requirements for the world excluding centrally planned economies. Indeed, by the year 2010 production from known reserves of conventional oil will be approaching exhaustion. New reserves were accounted for in the analysis. Cases like Mexico illustrate the point. But more is required. Unconventional oil such as that obtained from tar sands, oil shales, heavy crudes, and enhanced recovery take over an ever larger share. After the year 2000 it becomes necessary to add coal liquefaction, yielding a total oil production outside region VI that still does not meet the minimum demand of liquids required for chemical feedstocks and transportation. Continued imports from region VI are necessary, and it is indeed one of the crucial assumptions in the analysis that region VI would continue to have a production ceiling of 33 million barrels of oil per day. This ceiling is 50 percent greater than the 1975 oil production of this region, and about 30 percent above its 1977 production rate. Region VI is not the OPEC (Table 5 explains the relation between these two entities). So the conclusion is that the worldwide struggle for oil will continue; only some time after the year 2030 could this situation change. Obviously, one also has to envisage. lower production ceilings in region VI. This leads quickly to very awkward situations. More unconventional sources of energy would be required and even more coal liquefaction. We studied the consequences of having a ceiling of 30 million barrels of oil per day and found them tough. In view of the general lack of elasticity in the oil market, adjustments of demand will also be tough. Reduced economical growth rates are a most likely consequence.

But what about the availability of resources? An attempt to explain this is made in Table 6. One should note the difference between $837 \mathrm{TW}$-year for the grand total and $281 \mathrm{TW}$-year for the conventional resources ( $281 \mathrm{TW}$-year relates roughtly to 200 billion tons of oil equivalent). The difference between 837 and 281 TW-year is made up by unconventional resources (see also Fig. 5). For example, in region I the $126 \mathrm{TW}$ -

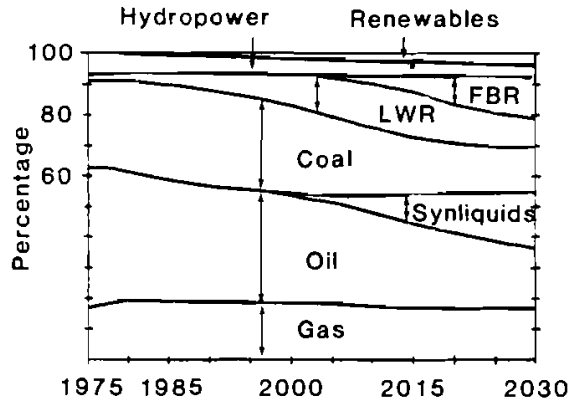

Fig. 4. Global primary energy, high scenario, 1975 to 2030 .

year of oil shale and tar sands refers to deposits in such areas as Colorado in the United States and Athabaska in Canada; the $178 \mathrm{TW}$-year refers mostly to the Orinoco area in Venezuela. The potential of these areas is equal to or larger than that of the Persian Gulf. But the necessity to use these resources, as is indicated in

Fig. 5, implies tremendous environmental consequences. Despite all the environmental analysis already performed today, this situation provides a new dimension of its own that requires more work and imagination. A natural reaction would be to declare the use of these deposits undesirable and perhaps infeasible. But the overall global balance between demand and supply must be kept in mind. It is particularly region III that would have to look for alternatives. One such alternative would be gas from region II and perhaps region VI-with all the geopolitical consequences; this requires a separate consideration (/3).

\section{World Oil Exports}

How are these exports of region VI allocated to the other regions? The answer to this question requires a major study

Table 6. Ultimately recoverable oil resources (all numbers in terawatt-years).

\begin{tabular}{|c|c|c|c|c|c|}
\hline \multirow[b]{2}{*}{ Region } & \multirow[b]{2}{*}{$\begin{array}{c}\text { Conven- } \\
\text { tional }\end{array}$} & \multicolumn{3}{|c|}{ Unconventional } & \multirow[b]{2}{*}{ Total } \\
\hline & & $\begin{array}{c}\text { Deep } \\
\text { offshore } \\
\text { and } \\
\text { polar areas }\end{array}$ & $\begin{array}{l}\text { Enhanced } \\
\text { recovery }\end{array}$ & $\begin{array}{l}\text { Oil shale } \\
\text { and } \\
\text { tar sands }\end{array}$ & \\
\hline I & 26 & 12 & 10 & 126 & 174 \\
\hline II & 43 & 12 & 20 & 76 & 151 \\
\hline III & 15 & 7 & 6 & 13 & 41 \\
\hline IV & 23 & & 8 & $178^{*}$ & 210 \\
\hline $\mathrm{V}$ & 23 & 13 & 7 & 20 & 63 \\
\hline VI & 139 & & $\dagger$ & $20 \ddagger$ & 159 \\
\hline VII & 12 & 8 & 5 & 14 & 39 \\
\hline Total§ & 281 & 52 & 56 & 447 & 837 \\
\hline
\end{tabular}

*Includes $170 \mathrm{TW}$-year of heavy crude oil. †Region VI is not expected, within the next 50 years, to make extensive use of tertiary recovery techniques. $\quad$ Includes heavy crude oil and some possibly deep offshore oil. §The analysis of region VII is necessarily rough, because few published data are available.

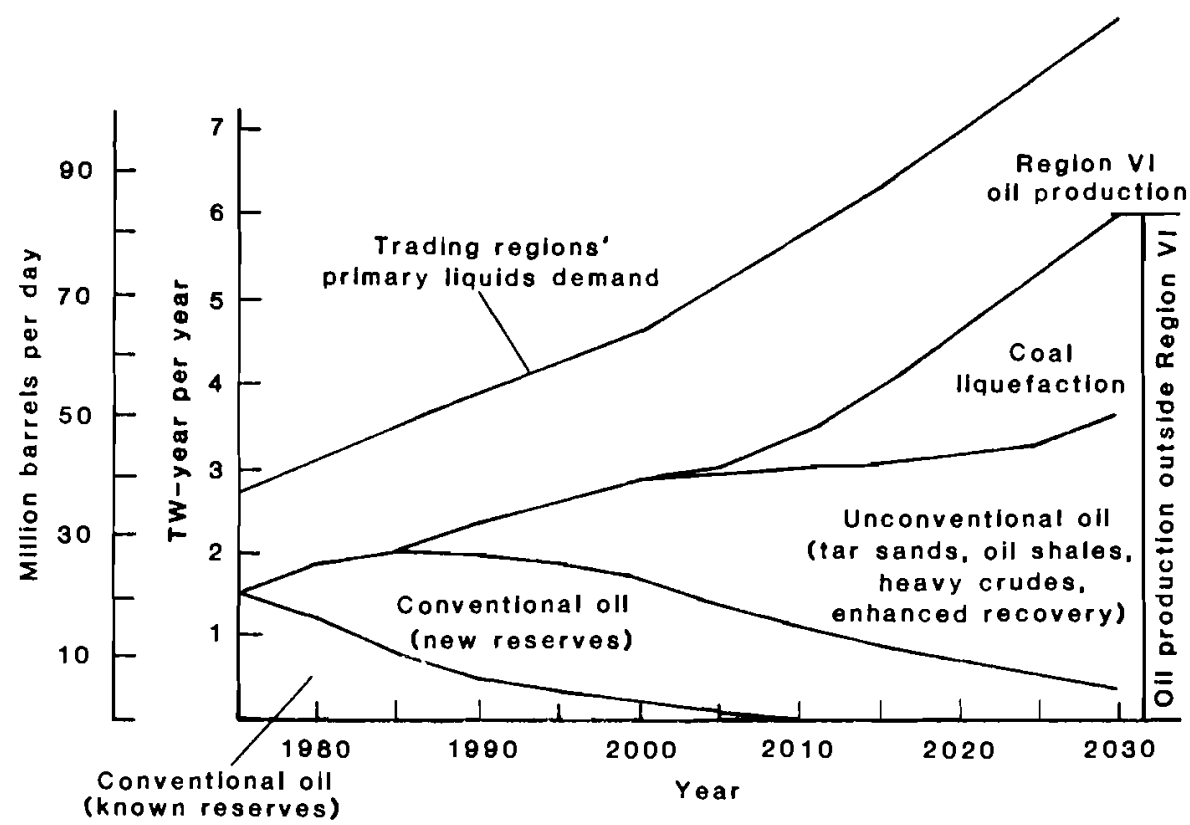

Fig. 5. Oil supply and demand, 1975 to 2030 for the world, excluding centrally planned economies, high scenario. 
on the future of world trade. Such a study has not yet been possible at IIASA, because it requires more economical than energy-analytical skills. It has been possible, however, to sketch a trading scenario by using an interregional gaming routine developed by the Siberian Power Institute at Irkutsk. For this routine it is assumed that region $\mathrm{Vl}$ dominates the market and that region VI wants to maximize its revenues within the production ceiling of 33 million barrels of oil per day, using it for both export from the region and domestic consumption in the region. Limiting factors are the synfuels as produced in the importing regions. The result is given in Fig. 6. The scenarios point to a situation where regions I, II, IV, and VII are selfsufficient in 2030. This means that the exports from region VI are going only to two regions: III and V. Western Europe and Japan must compete with the developing countries of region $\mathrm{V}$, and region III must reduce its oil imports to let region $\mathrm{V}$ have its share. Again one must point to the geopolitical implications (13).

\section{Coal and Nuclear Power}

Coal can be considered in a similar manner. Unusually high figures for yearly productions have to be assumed: in region $I$ up to 2700 million tce per year, in region II up to 3500 million tce per year, and in region III up to 1000 million tce per year. Both regions I and II are asked in the scenarios to assume an export function for coal much in the same sense as region VI is asked to export oil. An indicative figure for regions I and $\mathrm{II}$ in the high scenario is 600 million tce each by the year 2030 . All this comes on top of the above considered production of oil from shale oils and tar sands. Today this appears inconceivable, but the global energy problem is just of that dimension. In any event, one has to expect coal to be in short supply after the year 2000. While it seems natural to go into autothermal coal liquefaction and gasification schemes today, such shortages of coal supply after the year 2000 may force the use of allothermal liquefaction and gasification schemes, because these would reduce the demand for coal used for synfuels by a factor of roughly 3 to 4 . Apart from coal supply, there is the problem of carbon dioxide production from fossil fuels, which might equally demand the use of allothermal schemes. However, the two reference scenarios imply autothermal liquefaction schemes. For these two scenarios the re-

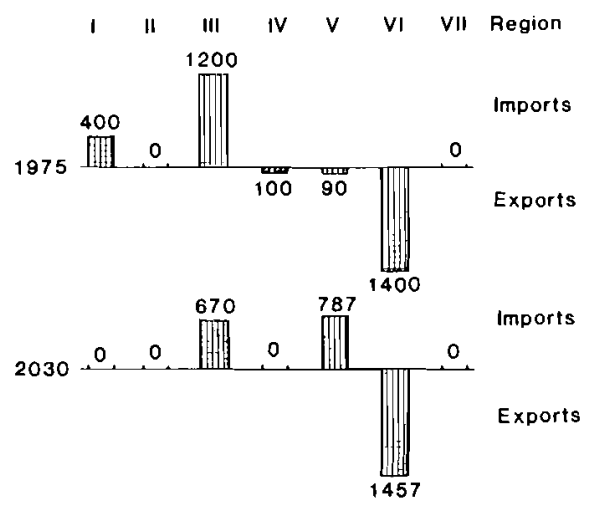

Fig. 6. Oil trading between regions in 1975 and 2030, high scenario (gigawatt-year per year; 1 $G W$-year per year $=14,000$ barrels of oil per day).

lated $\mathrm{CO}_{2}$ buildup is given in Fig. 7, according to Niehaus' model (14). Even today the situation looks serious.

Nuclear power in the supply scenarios is represented on a medium scale. As mentioned earlier, the $5.17 \mathrm{TW}$-year per year of the low scenario relate to 3000 GW-electric of installed capacity by the year 2030. In the high scenario the respective figures are 8.09 TW-year per year and $4800 \mathrm{GW}$-electric. In the analysis it was concluded that not more than $10,000 \mathrm{GW}$-electric could be installed by the year 2030 even if there were a worldwide and lasting effort to develop nuclear power. However, some additional nuclear potential may exist that could be used when obtaining fossil power-from unconventional fields-becomes too cumbersome. The generation of hydrogen by electrolytic or thermolytic means could, for instance, facilitate the allothermal schemes of coal liquefaction or gasification. If nuclear power were to be installed on such a scale, it would be necessary in any event to base it on the principle of breeding, because the integrated demand for uranium comes close to 8.5 million tons in our high scenario. In practice it is not intended to restrict the use of nuclear power to light-water reactors and fast breeders. All prudent reactor strategies, including the high-temperature and the heavy-water reactors, should be employed as long as the global supply conditions for natural uranium (and thorium) are kept in mind. There have been many studies on this subject, for example, those of INFCE (International Fuel Cycle Evaluation), so it is unnecessary to go into greater detail here. However, a word on fusion must be added. Strategically, fusion can substitute for the breeder reactor because it produces primarily electricity and is de facto decoupled from the resource question. There are also many other similar- ities between the fusion and the fast breeder reactor $(15)$. But it is considered unlikely that a fusion capacity greater than, say, $1000 \mathrm{GW}$-electric could be installed before the year 2030. Although its strategic potential might be utilized, essentially this will be after the year 2030 .

\section{Hard and Soft Solar Power}

It is necessary to distinguish between hard and soft solar power. Hard solar power refers to large solar power fields that might be installed, for instance, in the Sahara or in other sunny desert areas. Assuming an effective density of 20 watts per square meter for the production of solar electricity, it would take only 500,000 square kilometers to install a capacity of 10 TW-electric. Such an amount of land is not unreasonable; one may recall, for example, that all agricultural land on earth adds up to about 13 million square kilometers. However, the production of solar energy requires that the land put aside for this purpose be covered with materials, regardless of the particular solar technology to be used. The materials installed may amount to 100 kilograms per square meter (16), if one includes the hardware used to protect the solar collectors from the elements. These are typical systems effects that are often not taken into account when a new technology is first being considered. Only when the technology reaches a later stage of development do such effects come into view and then tend to dominate. If it is assumed that each year, 500 million tons of materials would have to be set aside just for solar power installations, this would imply a buildup rate of $100 \mathrm{GW}$-electric per year. It must be emphasized that 500 million tons per year is a large figure; today's world production of cement and steel amount to about 700 million tons per year. This leads us to the conclusion that the production capacity of solar power could not reach a dozen terawattyear per year or so until after the year 2030 , as is the case for fusion. And in both cases we have disregarded the question of costs.

What is left is the soft version, or local use, of solar power. Such power might very well be of local significance; however, on a global scale its contribution is limited. For example, the total roof area per capita may amount to $\mathbf{4 0}$ square meters, but only one-fourth of this area might be suitable for collecting solar power. With 40 watts per square meter of effective solar power being harnessed in the low-temperature domain, one 
would obtain 400 watts per capita, or, for 8 billion people, a total of $3.2 \mathrm{TW}$-year per year. This back-of-an-envelope calculation does not take into account such problems as low-temperature storage or costs or special local conditions. But the argument is sufficiently robust to conclude that such soft solar power does not match the scale of global energy demand. It turns out to be a valuable but limited contribution. In the scenarios, both high and low, the contributions of soft solar may be some what too small. In a linear programming approach, which optimizes discounted costs, it is difficult to arrive at meaningful estimates for the year 2030 and the seven world regions of the whole globe. But is is maintained that the contribution from soft solar energy will be a few terawatt-year per year, not a few dozens of terawatt-year per year.

\section{Other Renewables}

In addition to solar power there are the renewable energy sources with a somewhat local character that invite special consideration. Indeed, because local conditions are different and sometimes special, there are important local opportunities that do not become explicit in a global study. Often these sources are referred to as "soft"; however, it is interesting to make estimates of the global potential of such local, renewable sources. Hydropower seems to have a potential of $2.2 \mathrm{TW}$-electric of generating capacity (17), and this figure is hardly disputed. The renewables that remain include biomass, geothermal, and wind energy. In the analysis that underlies this article, it is concluded that the energy from these sources might add up to 2 or 3 TW-year per year. These upper limits are not well defined and therefore are potentially controversial. However, it should be kept in mind that soft energy sources become harder as the scale on which they are produced increases. Therefore there is agreement with proponents of soft energy paths that the soft renewables could have a global total potential in the order of $8 \mathrm{TW}$-year per year. Hard solar power is to be added to this figure.

With 8 billion people by the year 2030 . $8 \mathrm{TW}$-year per year would mean $1 \mathrm{~kW}$ year per year per capita as the global average. Today's average is $2 \mathrm{~kW}$-year per year per capita. As mentioned before, it is not physically impossible to live with 1 kW-year per year, especially once capital (and time) is available for the substitution of services from energy with services from capital, labor, and knowhow. But the IIASA analysis also makes
Fig. 7. Carbon dioxide emissions (--) (measured as tons of carbon per year), atmospheric $\mathrm{CO}_{2}$ concentration $(-\ldots)$, and temperature change (- - (A) High scenario. (B) Low scenario.

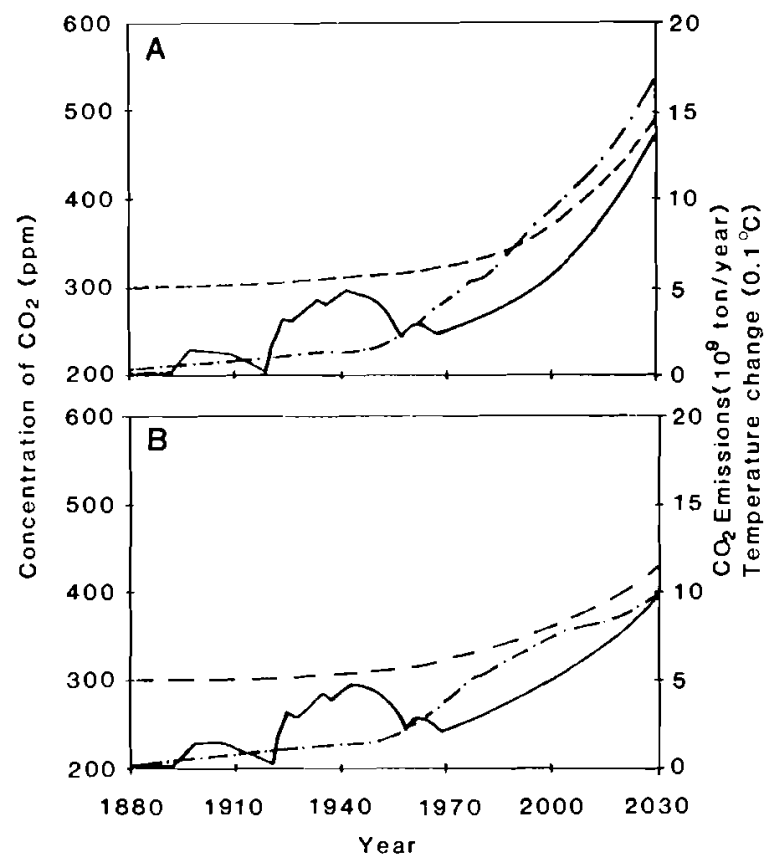

it clear that drastic changes of the structure of the economy would be required. This has far-reaching social and political implications and leads to the question of what happens politically when the gross national product of one group of nations consists of 20 percent steel and 80 percent arts, and the gross national product of another group of nations is nominally equal but consists of 80 percent steel and 20 percent arts. In fact, the hard-soft controversy is mostly a political one; the physical science aspects are rather clear.

\section{Energy from Gas}

In the reference scenarios, the cautious assumption was made that gas would not be transported intercontinentally. Thus gas is of regional significance only and its contribution, while increasing in absolute terms, remains somewhat constant in relative terms. The resource situation allows for higher energy contributions from gas, but only for a couple of decades given today's knowledge. Where $837 \mathrm{TW}$-year is the total recoverable oil (see Table 6), 538 TW-year is the total recoverable gas, its share of conventional resources being $267 \mathrm{TW}$-year.

Given the limited supply opportunities, it is likely that the problems of intercontinental transportation of gas will be solved. The technical problems associated with LNG (liquid natural gas) tankers and large-diameter or high-pressure pipelines. as well as methane-methanol conversions, are not insurmountable. Hydrogen produced by electrolysis or thermolysis using energy from nonfossil sources such as nuclear breeders and solar power would be suitable for an extension of the infrastructure for the transport and distribution of natural gas. It could thus allow for a certain flexibility of energy strategies that might be required in view of the $\mathrm{CO}_{2}$ problem, or in view of other shortcomings on the supply end of oil and coal.

\section{A Word on Cost Ranges}

It is true that the analysis did not start on the side of costs and prices, but nevertheless, that aspect was constantly monitored. On the supply side, oil and natural gas production costs were considered. Note that these were costs and not prices. By definition we arbitrarily eliminated the political and, specifically, the monetary aspects of the problem. Actually, three cost categories were considered: $\$ 0$ to $\$ 12, \$ 12$ to $\$ 20$, and $\$ 20$ to $\$ 25$ per barrel of oil equivalent. For coal the categories were: $\$ 0$ to $\$ 25$ per ton and $\$ 25$ to $\$ 50$ per ton; and for uranium, $\$ 80$ and $\$ 80$ to $\$ 130$ per kilogram of uranium. All figures are in constant 1975 dollars. The linear program then picked resources as necessary. In additon, capital costs were entered into the linear program. They ranged from $\$ 170$ per kilowatt for gas turbines up to $\$ 920$ per kilowatt for the fast breeder reactors, up to $\$ 1900$ per kilowatt for solar central stations in the case of electricity generation. and from $\$ 60$ to $\$ 320$ per kilowatt of secondary energy in the case of district heating. The weighted average cost of final energy thus increases by a factor of 2.4 to 3.0 between 1972 and 2030 . 


\section{Observations}

It is not too difficult to envisage a satisfactory energy system for even more than 8 billion people in the long-distance future. As secondary energy, such a system would make use of electricity and hydrogen; as primary energy, nuclear power from fusion or fission breeder reactors would be used as well as solar power. The carbon atom would be used for the most part only insofar as reduced carbon is produced by photosynthesis. In effect this would mean the recycling of $\mathrm{CO}_{2}$. In this event the problems associated with obtaining fossil resources and disposing of $\mathrm{CO}_{2}$ would be eliminated. The next 50 years is too brief a period for a complete transition from fossil to nonfossil energy sources. By the year 2030, perhaps 30 percent of primary energy could come from nonfossil resources. But within the period up to 2030 there is another superimposed transition, that is the transition from conventional and cheap fossil fuels to unconventional and expensive ones. This superimposed transition becomes necessary because even the somewhat modest rates of economic and population growth exceed the rates with which the infrastructure for energy supply and demand can change. We observed above that the most precious resource is time. Indeed, the more time we waste the deeper we have to go into the use of unconventional fossil resources. This is shown in Table 4 . In the absence of a proper approach this could have far-reaching environmental consequences, for which appropriate abatement measures should be envisaged. The two transitions should be harmonized; the carbon atom should be used prudently. The use of allothermal coal liquefaction or gasification schemes is a case in point. But the buildup of appropriate infrastructures must also be considered in this context: adapting gas pipelines for the transport of hydrogen is an example.

The intertwining of the two transitions can also be differently expressed: during the next 50 years we will not really be resource-constrained; the constraints will only be developing. However, between 2030 and 2080 , the resource constraints will come to the forefront, and then the transition from fossil to nonfossil resources will have to be completed.

Balancing demand and supply on a worldwide basis required the use of all supply and demand opportunities. Coal, oil, and gas, as well as nuclear, were used extensively in the scenarios, together with significant energy conservation. In that sense there are few choices to be made: all opportunities must be utilized.

The world energy problem can be solved. But it will require great effort. Besides will power and determination, it will require a strategic view and prudence.

\section{References and Notes}

1. C. Marchetti, N. Nakicenovic, V. Peterka, F. Fleck, The Dynamics of Energy Systems and the Logistic Substitution Model, AR-78-1A/B/C. prepared for the Stiftung Volkswagenwerk, national Institute for Applied Systems Analysis, national Institute for Applied
Laxenburg. Austria, 1978). 2. Member countries: the United States, Soviet
Union, Great Britain, France, Federal Republic of Germany, Italy, Canada, Japan, Poland, Ger man Democratic Republic, Czechoslovakia and Bulgaria as well as Austria, Hungary, Sweden, Finland and the Netherlands.

3. W. Häfele, program leader, Energy in a Finite World, Report by the Energy Systems Program Group of the International Institute for Applied Systems Anaiysis (Ballinger. Cambridge in press)

4. P. Basile, The IIASA Set of Energy Models: Its Design and Application (International Institute Design and Application (International Institute
for Applied Systems Analysis, Laxenburg, for Applied Systen

5. Commission of the European Communities, $\mathrm{Cru}$ - cial Choices for the Energy Transition. An Initial Evaluation of Some Energy $R$ \& $D$ Strat egies for the European Communities, EUR 6610 (Commission of the European Communities, Luxembourg. 19801.

6. N. Keyfitz, Population of the World and Its Regions. WP-79-119 (Intemational Institute for Applied Systems Analysis, Laxenburg, Austria 1979)

7. N. L. Hicks et al., "A model of trade and growth for the developing world," Eur. Econ. Rev. 7, 239 (1976).

8. B. Lapillonne, MEDEE 2: A Model for LongTerm Energy Demand Evolution. RR-78-17 (International Institute for Applied Systems Analyternational Institute for Applied

9. B. Chateau and B. Lapillonne, La Provision d

9. Chateau and B. Lapillonne, La Provision d
Long Terme de la Demande d'Energie (Editions CNRS, Paris, 1977)

10. M. Agnew, L. Schrattenholzer, A. Voss, A Model for Energy Supply Systems Alternatives and Their General Environmental Impact, WP79-6 (International Institute for Applied Systems Analysis, Laxenburg, Austria, 1979).

11. The energy and power units in this article are as follows: TW-year (1 terawatt-year $=10^{12}$ watt-year) equals 1 billion tons of coal equivalent (tce), or 0.7 billion ton of oil, or $0.86 \times 10^{12}$ cubic meters ( $30 \times 10^{12}$ cubic feet) of gas; 1 TW year per year is some 14 million barrels (of oil) per day. Gigawatt-year $\left(10^{9}\right.$ watt-year $)$ and kilowatt-year ( $10^{3}$ watt-year) are also used.

12. T. J. Connolly, U. Hansen. W. Jaek. K.-H Beckurts. World Nuclear Energy Paths (International Consultative Group on Nuclear Energy, New York and London, 1979)

13. W. Häfele, Foreign Aff., in press

14. F. Niehaus, A Nonlinear Eight Level Tandem Model to Calculate the Future $C O$ and C. 14 Burden to the Atmosphere RM-76-35 (lnternational Institute for Applied Systems Analysis Laxenburg, Austria, 1976).

15. W. Häfele, J. P. Holdren, G. Kessler, G. L. Kulcinski, Fusion and Fast Breeder Reactors RR-77-8 (International Institute for Applied Systems Analysis, Laxenburg. Austria, 1977). See also G. L. Kulcinski, G. Kessler, J. Holdren, W Häfele, $A m$. Sci. 67, 78 (1979).

16. See references in J. M. Weingart. Technol Forecast. Soc. Change 12, 273 (1978)

17. E. L. Armstrong, in World Energy Resources, 1985-2020. Executive Summaries to the Conservation Commission World Energy Conferservation Commission, World Energy Conference (IPC Science and Technology Press, Guildford, United Kingdom, and New York, 1978)
pp. 87-103.

18. Workshop on Alternative Energy Strategies, Energy: Global Prospects 1985-2000 (McGrawHill, New York, 1977).

19. V. G. Chant, Two Global Scenarios: Evolution of Energy Use and the Economy to 2030 (Inter national Institute for Applied Systems Analysis, Laxenburg, Austria, in press)

20. Department of Energy, International Energy Indicators (Department of Energy, Washington, D.C. April 1979).

21. Petroleum Intelligence Weekly Spec. Suppl. (5 February 1979).

22. This article. including Figs. $I$ to 7 and Tables 1 to 6, is based on Energy in a Finite World (3). 



\section{SELECTED ENERGY-RELATED PUBLICATIONS BY IIASA}

ENERGY IN A FINITE WORLD: PATHS TO A SUSTAINABLE FUTURE Report by the Energy Systems Program Group of IIASA, Wolf Häfele, Program Leader. 225 pp. $\$ 16.50$.

Written by Jeanne Anderer with Alan McDonald and Nebojß̌a Nakićenović

ENERGY IN A FINITE WORLD: A GLOBAL SYSTEMS ANALYSIS

Report by the Energy Systems Program Group of ILASA, Wolf Häfele, Program Leader. 837 pp. $\$ 45.00$.

Both of the above volumes are available from Ballinger Publishing Company, 17 Dunster Street, Cambridge, Massachusetts 02138, USA.

The other publications listed here are divided into five subject areas:

1 Global, regional, and sectoral energy models - whether for energy demand, energy supply and conversion, or for economic, resource, or environmental impacts of energy technologies.

2 The analysis of different energy sources - i.e., fossil fuels, nuclear power, solar power and other renewebles - and the conversion, storage, and transportation technologies associated with them.

3 The analysis of energy dernand petterns.

4 Environmental and safety risks of energy technologies.

5 The analysis of total energy systems and energy strategies including all the dimensions of the first four categories taken together. 


\section{Energy Models}

RR-80-31. The IIASA Set of Energy Models: Its Design and Application. P.S. Basile. December 1980.65 pp. $\$ 7.00$

RR-78-17. MEDEE-2: A Model for Long-Term Energy Demand Evaluation. B. Lapillonne. November 1978.45 pp. $\$ 6.00$

RR-79-8. The Economic IMPACT Model. Yu.D. Kononov, A. Por. October 1979. 72 pp. $\$ 8.50$

The Energy Supply Model MESSAGE. L. Schrattenholzer. 1981. (Forthcoming Research Report.)

A Long-Term Macroeconomic Equilibrium Model for the European Community. H.H. Rogner. 1981. (Forthcoming Research Report.)

Modeling of Large-Scale Energy Systems. Proceedings of the IIASA-IFAC Symposium on Modeling of Large-Scale Energy Systems. W. Häfele, Editor, L.K. Kirchmayer, Associate Editor. 1981. 462 pp. (Available from Pergamon Press.) $\$ 72.00$

CP-74-3. Proceedings of IIASA Working Seminar on Energy Modeling, May 28-29, 1974. May 1974. 342 pp. $\$ 13.00$

RR-74-10. A Review of Energy Models: No. 1 - May 1974. J.P. Charpentier, Editor. July 1974. 102 pp. $\$ 8.50$

RR-75-35. A Review of Energy Models: No. 2 - July 1975. J.-P. Charpentier, Editor. October 1975. 133 pp. $\$ 10.00$

RR-76-18. A Review of Energy Models: No. 3 (Special Issue on Soviet Models). J.-M. Beaujean, J.P. Charpentier, Editors. December 1976. 33 pp. $\$ 4.00$

RR-78-12. A Review of Energy Models: No. 4 - July 1978. J.-M. Beaujean, J.-P. Charpentier, Editors. July 1978.48 pp. $\$ 6.00$

CP-77-2. Methods of Systems Analysis for Long-Term Energy Development. Yu.D. Kononov, Editor. March 1977. 38 pp. $\$ 5.00$

RR-76-11. Modeling of the Influence of Energy Development on Different Branches of the National Economy. Yu.D. Kononov. October 1976.15 pp. (Microfiche only.) $\$ 4.00$

RR-79-13. The Dynamics of Energy Systems and the Logistic Substitution Model. C. Marchatti, N. Nakicenovic. December 1979. 73 pp. $\$ 8.50$

RR-79-12. Software Package for the Logistic Substitution Model. N. Nakicenović. December 1979. $69 \mathrm{pp} . \$ 7.00$

RA-77-22. Macrodynamics of Technological Change: Market Penetration by New Technologies. V. Peterka. November 1977, 128 pp. (Microfiche only.)

RR-80-28. Market Substitution Models and Economic Parameters. B.I. Spinrad. July 1980. 26 pp. $\$ 4.00$

Economic Evolutions and Their Resilience: A Model. M. Breitenecker, H.R. Grümm. 1981. (Forthcoming Research Report.)

Dynamic Linear Programming Models of Energy, Resources, and Economy Development Systems. A Propoi, I. Zimin. 1981. (Forthcoming Research Report.)

\section{Energy Sources}

North Sea Oil. Resource Requirements for Development of the U.K. Sector. J.K. Klitz. 1980. 260 pp. (Available from Pergamon Press.) $\$ 36.00$

Future Supply of Nature-Made Petroleum and Gas. R. Meyer, Editor. IIASA, UNITAR. 1977. 1046 pp. (Available from Pergamon Press.) Hard cover $\$ 60.00$, soft cover $\$ 40.00$ 
Conventional and Unconventional World Gas Resources. M. Grenon, C. Delaheye, Editors. 1981. (Forthcoming from Pergamon Press.)

Future Coal Supply for the World Energy 8alance. M. Grenon, Editor. 1979. 720 pp. (Available from Pergamon Press.) $\$ 90.00$

RR-80-20. Energy and Entropy Fluxes in Coal Gasification and Liquefaction Processes. H. Voigt. April 1980. 25 pp. $\$ 4.00$

CP-77-5. Medium-Term Aspects of a Coal Revival: Two Case Studies. Report of the IIASA Coal Task Force. W. Sassin, F. Hoffmenn, M. Sadnicki, Editors. August 1977. 90 pp. $\$ 8.50$

Methods and Models for Assessing Energy Resources. M. Grenon, Editor. 1979. 605 pp. (Available from Pergamon Press.) $\$ 75.00$

RM-78-35. On Fossil Fuel Reserves and Resources. M. Grenon. June 1978. 37 pp. $\$ 5.00$

RR-76-2. Studies on Energy Resources in the IIASA Energy Project. M. Grenon. January 1975. 42 pp. (Microfiche only.) $\$ 4.00$

RR-75-38. Transport and Storage of Energy. C. Marchetti. November 1975. 33 pp. \$5.00

RR-77-8. Fusion and Fast Breeder Reactors. W. Häfele, J.P. Holdren, G. Kessler, G.L. Kulcinksi. July 1977. 506 pp. $\$ 24.00$

RR-75-36. Considerations on the Large-Scale Development of Nuclear Fuel Crcles. R. Avenhaus, W. Häfele, P.E. McGrath. October 1975. 98 pp. $\$ 8.50$

RR-75-40. Application of Nuclear Power Other Than for Electricity Generation.W. Häfele, W. Sassin. November 1975. 120 pp. (Microfiche only.) $\$ 6.00$

RR-73-14. Hypotheticaity and the New Challenges: The Pathfinder Role of Nuclear Energy. W. Häfele. December 1973. 20 pp. $\$ 4.00$

RR-73-5. The Fast Breeder as a Cornerstone for Future Large Supplies of Energy. W. Hëfele. September 1973. 60 pp. $\$ 7.00$

The Possible Share of Soft, Decentralized Renewables in Meeting the Future Energy Demands of Developing Regions. A.M. Khen. 1981. (Forthcoming Research Report.)

RM-77-26. Mobilization and Impacts of Bio-Gas Technologies. J.K. Parikh, K.S. Parikh. November 1977.19 pp. $\$ 3.00$

RR 815. The Helios Strategy: A Heretical View of the Potential Role of Solar Energy in the Future of a Small Planet. J.M. Weingert. Reprinted from Technological Forecasting and Social Change, Volume 12 (4), pp. 273-315 (1978)

RR-77-20. Power from Glaciers: The Hydropower Potential of Greenland's Glacial Waters. R. Partl. November 1977. 52 pp. $\$ 7.00$

RR-76-7. On Hydrogen and Energy Systems. C. Marchetti. March 1976. 10 pp. (Microfiche only.) $\$ 4.00$

AM-78-62. Genetic Engineering and the Energy System: How to Make Ends Meet. C. Marchetti. December 1978. 11 pp. $\$ 4.00$

\section{Energy Demand}

Evolution of Future Energy Demand Till 2030 in Different World Regions: An Assessment Made for the Two IIASA Scenarios. A.M. Khan, A. Holzl. 1981. (Forthcoming Research Report.)

RR-79-15. Simulation of Macroeconomic Scenarios to Assess the Energy Demand for India (SIMA). J.K. Parikh, K.S. Parikh. December 1979. 59 pp. $\$ 7.00$

The growth of Energy Consumption and Prices in the USA, FRG, France and the UK, 1950-1979. C.P. Doblin. 1981. (Forthcoming Reseerch Report.) 
RM-78-46. Energy Demand by US Manufacturing Industries. C.P. Doblin. September 1978.43 pp. $\$ 6.00$

RM-76-43. German Democretic Republic: Energy Demand Data. C.P. Doblin. June 1976. 29 pp. (Microfiche only.) $\$ 4.00$

CP-76-1. Proceedings of the Workshop on Energy Demand. W.D. Nordhaus, Editor. January 1976. 880 pp. (Microfiche only.) $\$ 16.00$

RM-76-18. Date Provided for W.D. Nordhaus Study: The Demand for Energy: An International Perspective. C.P. Doblin. March 1976. 72 pp. $\$ 8.50$

\section{Environmental and Safety Risks}

Climate and Energy Systems. J. Jäger. 1981. (Forthcoming.)

Climatic Constraints and Human Activities. Task Force on the Nature of Climate and Society Research, February 4-6, 1980. J. H. Ausubel, A.K. Biswas, Editors. 1980. 214 pp. (Available from Pergamon Press.) $\$ 30.00$

CP-77-9. Climate and Solar Energy Conversion: Procerdings of a IIASA Workshop. December 8-10, 1976. J. Williams, G. Krömer. J.M. Weingart, Editors. December 1977. $\$ 9.50$

Carbon Dioxide. Climate and Society. J. Williams, Editor. 1978.332 pp. (Available from Pergamon Press.) $\$ 30.00$

RM-76-17. On Geoengineering and the $\mathrm{CO}_{2}$ Problem. C. Marchetti. March 1976. 13 pp. $\$ 4.00$

RR-75-45. The Carbon Cvcle of the Earth - A Material Balance Approach. R. Avenhaus, G. Hartmann. December 1975.27 pp. $\$ 4.00$

RR-80-30. Possible Climatic Consequences of a Man-Mada Globel Warming. H. Flohn. December 1980. 92 pp. $\$ 8.50$

RR-80-21. The Impect of Waste Heat Release on Climate: Experiments with a General Circulation Model. J. Williams, G. Krömer, A. Gilchrist. Reprinted from Journal of Applied Meteorology, Volume 18, pp. 1501-1511 (1979)

RR-80-15. A Comperative Study of Public Beliefs About Five Energy Systems. K. Thomas. D. Maver, M. Fishbein, H.J. Otway, R. Hinkle, D. Simpson. April 1980. 32 pp. \$5.00

RR-80-25. The Value of Humen Life: A Review of the Models. J. Linnerooth. Reprinted from Economic Enquiry, Volume 17,pp. 52-74 (1979)

RM-78-69. What Are We Talking About When We Talk About "Risk"? A Critical Survey of Risk and Risk Preference Theories. R.E. Scheefer. December 1978.54 pp. $\$ 7.00$

RR-75-14. Avoidance Response to the Risk Environment: A Cross-Cultural Comparison. H.J. Otway, R. Maderthaner, G. Guttmann. June 1975. 29 pp. (Microfiche only.) $\$ 4.00$

RR-80-18. Nuclear Energy: The Accuracy of Policy Makers' Perceptions of Public Beliefs. K. Thomas, E. Swaton, M. Fishbein, H.J. Otway. April 1980. 37 pp. $\$ 5.00$

Material Accountability: Theory, Verification, and Applications. R. Avenhaus. 1977. 188 pp. (Available from John Wiley and Sons Ltd.) $\$ 32.85$

RR-76-19. The WELMM Approach to Energy Strategies and Options. M. Grenon, B. Lapillone. December 1976. 41 pp. $\$ 6.00$

RA-76-13. Environmental Impects of Electricel Generation: A Systemwide Approach. W.K. Foell, W.A. Buehring. April 1976. 32 pp. (Microfiche only.) $\$ 4.00$ 


\section{Energy Systems and Energy Strategies}

RM-78-18. Energy Systems - The Broeder Context. C. Marchetti. April 1978. 14 pp. $\$ 4.00$

CP-76-7. Energy Systems: Global Options and Strategies. W. Häfole, 1976, in IIASA Conference '76. 574 pp. $\$ 10.00$

RR-76-8. Energy Strategies. W. Häfele, W. Sassin. March 1976. 37 po. (Microfiche only.) $\$ 4.00$

RR-73-1. Energy Systems. W. Häfele. July 1973. 45 pp. (Microfiche only.) $\$ 4.00$

RR-78-7. On 1012: A Check on Earth Carrying Capacity for Man. C. Marchetti. May 1978. 11 pp. $\$ 4.00$

RR-76-5. Definitions of Resilience. H.R. Grümm. March 1976. 20 pp. (Microfiche only.) $\$ 4.00$

Management of Energy/Environment Systems: Methods and Case Studies. W.K. Foell, Editor. 1979. 488 pp. (Available from John Wiley and Sons Ltd.) $\$ 39.50$

RR-79-10. On Energy and Agriculture: From Hunting-Gathering to Landless Farming. C. Marchetti. December 1979.13 pp. $\$ 4.00$

RR-74-20. Future Energy Resources. W. Höfele. November -1974. 28 pp. (Microfiche only.) $\$ 4.00$

The Nuclear Apple and the Solar Orange. Alternatives in World Energy. M. Grenon. 1981. 156 pp. (Available from Pergamon Press.) $\$ 36.00$

RR-76-10. Energy Strategies and the Case of Nuclear Power. W. Häfele. May 1976. 30 pp. $\$ 3.00$

RR-74-7. Strategies for a Transition from Fossil to Nuclear Fuels. W. Häfele, A.S. Manne. June 1974. 70 pp. (Microfiche only.) $\$ 4.00$

RR-75-47. An Extension of the Häfele-Manne Model for Assessing Strategies for a Transition from Fossil to Nuclear and Solar Alternatives. A. Suzuki. December 1975. 179 pp. (Microfiche only.) $\$ 6.00$

RA-80-27. Effects of Accounting Rules on Utility Choices of Energy Technologies in the United States. B.I. Spinrad. July 1980.32 pp. $\$ 5.00$

RR-76-6. A Systems Approach to Development Planning of the Fuel Power Industry of a Planned-Economy Country. L.S. Belyaev. March 1976. 23 pp. (Microfiche only.) \$4.00 CP-76-12. Systems Studies of Nuclear Energy Development in the USSR. L.A. Melentiev, A.A. Makarov, A. Belostotsky. December 1976.40 pp. $\$ 5.00$

RR-74-6. Energy Choices that Europe Faces: A European View of Energv. W. Häfele. March 1974. 37 pp. (Microfiche only.) $\$ 4.00$ 


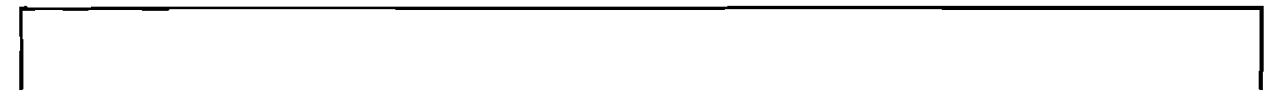

Books in the Internetional Series on Applied Systems Analysis (Wiley) can be ordered from John Wiley \& Sons Lid., Baffins Lane, Chichester, Sussex PO19 2UD, United Kingdom.

Books published by Pergamon Press can be ordered from Pergamon Press Lid., Headington Hill Hall, Oxford OX3 OBW, United Kingdom, or Pergemon Press, Inc., Fairview Park, Elmsford, N.Y. 10523, USA.

All other publications can be ordered from the Publications Department, IIASA, A-2361 Laxenburg. Austria. 